$\begin{array}{r}\text { Phinisi Integration Review } \\ \text { Vol. 2, No.2, Agustus 2019 Hal 271-280 } \\ \text { Website: http://ojs.unm.ac.id/pir } \\ \text { p-ISSN: 2614-2325 dan e-ISSN: 2614-2317 } \\ \text { DOI: https://doi.org/10.26858/pir.v2i2.10005 } \\ \hline\end{array}$

\title{
Kedudukan Visum Et Repertum Dalam Pengungkapan Delik Pembunuhan Di Wilayah Hukum Polrestabes Makassar
}

\author{
Lisdayanty \\ Universitas Negeri Makassar \\ Email : lisdayantylisda@gmail.com
}

\begin{abstract}
Abstrak. Penelitian ini bertujuan untuk mendeskripsikan persepsi masyarakat terhadap Visum Et Repertum dan kekuatan Visum Et Repertum dalam pengungkapan delik pembunuhan di wilayah polrestabes Makassar. Selain itu juga untuk mendalami faktor penghambat pembuatan Visum Et Repertum dalam pengungkapan delik pembunuhan. Penelitian ini menggunakan penelitian kualitatif deskriptif. Pengumpulan data dilakukan dengan cara observasi, wawancara, dan dokumentasi serta analisis data yang dilakukan melalui reduksi data, display dan verifikasi data. Temuan penelitian menunjukkan, 1) Persepsi Masyarakat terhadap Visum Et Repertum sebagai alat bukti dalam pengungkapan delik pembunuhan menolak dengan alasan telah mengiklaskan, rasa kasihan dengan jenazah, menganggap tindakan tersebut tidak manusiawi, dan faktor agama. 2). Kekuatan Visum Et Repertum memiliki kekuatan yang mutlak, namun Visum Et Repertum tidak mutlak dilakukan disetiap kasus pembunuhan. Kekuatan pembuktian Visum Et Repertum merupakan alat bukti yang sempurna tentang apa saja yang tercantum didalamnya. Visum Et Repertum tidak bisa berdiri sendiri karena setiap putusan pemidanaan harus tetap didasarkan dengan minimal dua alat bukti yang sah ditambah dengan keyakinan hakim.3) penghambat pembuatan Visum Et Repertum sebagai alat bukti dalam pengungkapan delik pembunuhan yaitu adanya opini masyarakat tentang pengambilan organ-organ tubuh mayat yang dilakukan dokter forensik.
\end{abstract}

Kata kunci: Visum Et Repertum, persepsi masyarakat, kekuatan.

\begin{abstract}
This study ains to describe community perceptions of Visum et Repertum and the strength of Visum et Repertum in disclosure of murder offenses in polrestabes are in Makassar. In addition, it aims at examining the inhibiting factors in making Visum et Repertum in disclosure of murder offenses. The study employed qualitative and descriptive research. Data were collected by employing observation, interview, and documentation. Data were analyzed by conducting data reduction, data display, and data verification. The resulst of the study reveal that 1 ) the community perceptions on Visum et Repertum as the evidence in disclosure murder offenses rejected with the reason of letting it go sincerely, feel pity to the corps, consider the action as inhuman, and the religious dactor. The ones who agreed to be examined but only permitted by the famly to conduct external examination, 2) the strength of Visum et Repertum has absolute power of Visum et Repertum is not absolutely done in every murder case. The proof power of Visum et Repertum is the perfect proof of what is included in it. Visum et Repertum cannot stand alone because every sentencing decision must be based on a minimum of two valid evidences coupled with a judge's conviction, 3) the inhibitor of making Visum et Repertum as evidence in the disclousure of murder offenses is the existence of public opinion about the organs of the body carried out by forensic doctors.
\end{abstract}

Keywords: Visum et repertum, community perceptions, strength 
cc) (i) (-) Ini adalah artikel dengan akses terbuka dibawah licenci CC BY-NC-4.0 https://creativecommons.org/licenses/by-nc/4.0/ ).

\section{PENDAHULUAN}

Negara Indonesia adalah Negara hukum yang berdasarkan pada pancasila dan Undang-Undang Dasar Negara Republik Indonesia Tahun 1945 pasal 1 ayat (3) yang menyatakan bahwa "Negara Indonesia adalah Negara Hukum". Hal ini berarti Negara Indonesia menjunjung tinggi hak asasi manusia dan menjamin segala warga negaranya bersamaan kedudukannya di dalam hukum dan pemerintahan tanpa ada pengecualian. Hukum merupakan tiang utama dalam menggerakkan sendi-sendi kehidupan bermasyarakat, berbangsa dan bernegara.

Negara dengan konsep negara hukum selalu mengatur setiap tindakan dan tingkah laku warga negaranya berdasarkan atas undangundang yang berlaku untuk menciptakan, memelihara, mempertahankan kedamaian pergaulan hidup dan pemeritah harus menjamin adanya penegakan hukum agar tercapaianya tujuan hukum yaitu keadilan, kemanfaatan, dan kepastian hukum agar sesuai dengan apa yang diamanatkan dalam Pancasila dan UUD 1945.

Dalam Negara Republik Indonesia juga dilindungi hak-hak asasi manusia dalam bidang hukum bagi setiap warga Negara yang menyatakan bahwa tidak seorangpun dapat dihadapkan di pengadilan selain ditentukan oleh peraturan perundang-undangan yang berlaku. Hukum dibuat, tumbuh dan berkembang dalam masyarakat dengan tujuan untuk mengatur kehidupan masyarakat yang ada diwilayah tersebut, agar tercipta ketertiban, ketenangan, kedamaian, dan kesejahteraan. Hukum merupakan aturan yang mengatur tingkah laku manusia dalam kehidupannya karena tanpa adanya hukum, tidak dapat dibayangkan kondisi Negara ini.

Berdasarkan data dari survey Badan Pusat Statistik (BPS) per maret 2017, Salah satunya kejahatan yang sering terjadi dimasyarakat adalah kejahatan terhadap nyawa atau sering disebut dengan pembunuhan. Pembunuhan merupakan tindak pidana yang sangat berat dan cukup mendapatkan perhatian pada kalangan masyarakat. Kasus pembunuhan di Indonesia baik kasus pembunuhan yang dengan diawali tindak kekerasan terhadap korbannya ataupun pembunuhan yang telah direncanakan sebalumnya, telah diatur dalam Kitab Undang-Undang Hukum Pidana.

Tindak pidana pembunuhan adalah suatu perbuatan yang dengan sengaja maupun tidak, menghilangkan nyawa orang lain. Pada ketentuan peraturan perundang-undangan yang tercantum dalam Kitab Undang-Undang Hukum Pidana (KUHP) mengatur salah satunya tentang tindak pidana pembunuhan yang tertuang pada pasal 338-350 KUHP. Ancaman terberat pada tindak pidana kejahatan terhadap nyawa adalah pembunuhan berencana yang tercantum pada pasal 340 KUHP.

Untuk memperoleh alat bukti yang diperlukan dalam mengungkap suatu tindak pidana, seringkali penegak hukum dihadapkan pada suatu masalah atau hal-hal tertentu yang tidak dapat diselesaikan sendiri karena masalah tersebut diluar batas kemampuannya atau keahliannya. Sehingga dalam hal demikian sangat diharapkan bantuan seorang ahli untuk mendapatkan kebenaran materil selengkap lengkapnya bagi para penegak hukum yang ditegaskan pada pasal 120 ayat (1) KUHAP

Terkait dengan bantuan keterangan ahli yang diperlukan dalam proses suatu perkara pidana, kasus tindak pidana pembunuhan merupakan kasus dimana penyidik membutuhkan bantuan tenaga ahli seperti dokter forensik atau dokter ahli lainnya, untuk memberikan keterangan medis tentang kondisi korban yang selanjutnya berpengaruh bagi tindakan penyidik dalam mengungkap lebih lanjut kasus tersebut. Ditegaskan pada Pasal 133 kitab Undang-undang Hukum Acara Pidana, Berdasarkan Surat Keputusan Menteri Kehakiman No.M04/UM/01.06 tahun 1983 pada Pasal 10. Secara etimologi Visum Et Repertum adalah apa yang dilihat dan diketemukan. Visum Et Repertum pada mayat dibuat berdasarkan otopsi lengap dengan kata lain berdasarkan pemeriksaan luar dan pemeriksaan dalam pada mayat.

Dalam pembuktian suatu perkara pidana yang menyangkut jiwa/pembunuhan atau tubuh seseorang, alat bukti Visum Et Repertum sangat berperan untuk mengetahui sebab kematian,menentukan atau memperkirakan cara kematian dan penyebab suatu luka seseorang 
terlebih lagi pada delik pembunuhan. Visum Et Repertum tidak mampu menunjukka pelaku tindak pidana, Visum Et Repertum tetap berpengaruh terhadap penjatuhan hukuman bagi tersangka pelaku tindak pidana, karena dalam Visum Et Repertum dapat diketahui penyebab kematian korban, apakah pembunuhan dilakukan dengan menggunakan senjata tajam atau tumpul dan untuk mengetahu apakah pembunuhan dilakukan diawali, disertai dan atau diikuti tindak pidana lain seperti pemerkosaan.

Visum Et Repertum dapat dikeluarkan setelah dilakukan pemeriksaan pada tubuh jenazah, Visum Et Repertum dibuat agar suatu perkara pidana menjadi jelas dalam hal penyebab kematian korban dan berguna bagi kepentingan pemeriksaan untuk keadilan serta diperuntukkan bagi kepentingan peradilan, artinya Visum et Repertum sangat diperlukan oleh seorang hakim dalam membuat sebuah keputusan dalam sebuah persidangan untuk menjatuhkan pidana kepada tersangka tindak pidana pembunuhan.

Visum Et Repertum dalam kasus delik pembunuhan adalah salah satu alat bukti, Visum Et Repertum sangat penting dalam pembuktian kasus tindak pidana salah satunya yaitu tindak pidana pembunuhan atau kematian seseorang yang tidak wajar dikarenakan hasil dari pemeriksaan pada tubuh mayat yang dilakukan dokter forensik akurat dalam membuktikan penyebab kematian dan waktu kematian. Permintaan pemeriksaan terhadap tubuh mayat dapat dilakukan oleh penyidik setelahmendapatkan persetujuan dari pihak keluarga mayat. Masih adanya penolakan dari pihak keluarga mayat untuk dilakukan pemeriksaan pada tubuh mayat dan kurangnya pemahaman masyarakat mengenai Visum Et Repertum, Hal ini terlihat dari kasus yang terjadi di ruang jenazah rumah sakit di Manado Sulawesi Utara. Kekacauan yang terjadi karena pihak kerabat dan keluarga jenazah melihat tubuh jenazah terdapat luka jahitan hasil autopsi dan menuduh dokter mengambil organ-organ dalam tubuh jenazah.

\section{TINJAUAN PUSTAKA}

\section{A. Sosiologi Hukum}

Sosiologi hukum memandang hukum sebagai kenyataan sosial dan bukan kaidah. Sosiologi hukum memandang hukum sebagai fenomena sosial yang berbeda dengan hukum normatif yang memandang hukum sebagai norma-norma positif di dalam perundang- undangan hukum nasional. Soerjono Soekanto (2002:9) Kajian sosiologi hukum adalah suatu kajian yang objeknya fenomena hukum tetapi menggunakan topik ilmu sosial dan teori-teori sosiologis, sehingga sering disalah tafsirkan bukan hanya oleh kalangan non hukum tetapi juga dari kalangan hukum sendiri.

\section{B. Persepsi Masyarakat tentang Visum Et Repertum}

Pengertian Presepsi dalam kamus ilmiah adalah pengamatan, penyusunan, dorongandorongan dalam kesatuan-kesatuan, hal mengetahui, melalui indera tanggapan (indera) dan daya memahami. Persepsi atau dalam bahasa inggris perception berasal dari bahasa latin perception; dari percipere, yang artinya menerima atau mengambil (Alex Sobur 2003:445). peresepsi dalam arti sempit adalah penglihatan atau bagaimana cara seseorang melihat sesuatu. sedangkan dalam arti luas peresepsi adalah pandangan seseorang mengenai bagaimana ia mengartikan dan menilai sesuatu. peresepsi pada hakikatnya adalah proses kognitif yang dialami oleh setiap orang dalam memahami informasi tentang lingkungannya, baik lewat penglihatan, pendengaran, penghayatan, perasaan, dan penciuman. kunci untuk memahami presepsi ialah terletak pada pengenalan bahwa peresepsi merupakan suatu penafsiran yang unik terhadap situasi, dan bukannya suatu pencatatan yang benar terhadap situasi ( Akyas Azhari 2004:107).

Indikator persepsi ada 3, yaitu tanggapan, pendapat dan penilaian. adapun penjelasannya sebagai berikut :

1) Tanggapan

2) Pendapat.

3) Penilaian

Di Indonesia autopsi forensik tidak merupakan keharusan bagi semua kematian, namun sekali diputuskan oleh penyidik perlunya otopsi maka tidak ada lagi yang boleh menghalangi pelaksanaannya (pasal 134 KUHAP dan pasal 222 KUHP), dan tidak membutuhkan persetujuan keluarga terdekatnya. Sehingga masyarakat dapat mengatur jalannya hukum, ini sesuai dengan hal yang dikemukakan oleh Lawrence M.Friedman (2001:8) bahwa budaya hukum adalah sikap manusia terhadap hukum dan sistem hukum, kepercayaan,nilai,pemikiran serta harapannya.

\section{Visum Et Repertum}

Dalam kamus umum Bahasa Indonesia Visum et repertum berarti hasil pemeriksan dokter (di bawah sumpah) tentang pemeriksaan 
medis seseorang yang masih hidup atau sudah menjadi mayat untuk keperluan pemeriksaan pengadilan. Dipandang dari etimologi atau tata bahasa, kata "Visum" atau "Visa" berarti tanda melihat atau melihat yang artinya penandatanganan dari barang bukti tentang segala sesuatu hal yang ditemukan, disetujui, dan disahkan, sedangkan "Repertum" berarti melapor yang artinya apa yang telah didapat dari pemeriksaan dokter terhadap korban. Secara etimologi Visum Et Repertum adalah apa yang

Dalam Undang-undang Nomor 8 tahun 1981 KUHP tidak disebut Visum et repertum tetapi menggunakan istilah alat bukti surat dan alat bukti keterangan ahli. Pasal 1 butir 28 KUHAP memberikan pengertian tentang keterangan ahli Visum et repertum berkaitan erat dengan ilmu kedokteran forensik. R.atang Ranoemihardja (1983 : 10). Visum et repertum dijadikan sebagai alat bukti dalam menangani kasus untuk membantu proses peradilan saat sidang di pengadilan. Peran dokter sebagai ahli forensik, korban yang diperiksa berstatus sebagai barang bukti sebagaimana telah diatur dalam peraturan perundang-undangan.

Tujuan Visum Et Repertum adalah, untuk memberikan kepada hakim (Majelis) suatu kenyataan akan fakta-fakta dari buktibukti tersebut atas semua keadaan/hal sebagaimana tertuang dalam bagian pemberitaan agar hakim dapat mengambil keputusannya dengan tepat atas dasar kenyataan atau faktafakta tersebut, sehingga dapat menjadi pendukung atas keyakinan hakim. (R. Soeparmono 2002:100)

Adapun macam-macam Visum et repertum terbagi dalam:

a. Dilihat dari sifatnya.

b. Dilihat dari hasil laporan pemeriksaan dokter ahli.

Agar didapat keseragaman mengenai bentuk pokok Visum Et Repertum, maka ditetapkan ketentuan mengenai susunan Visum Et Repertum sebagai berikutu:

a. Pada sudut kiri atas dituliskan "PRO YUSTISIA", artinya bahwa isi Visum Et Repertum hanya untuk kepentingan peradilan.

b. Di tengah atas dituliskan jenis Visum Et Repertum serta nomor Visum Et Repertum tersebut.

c. Bagian pendahuluan, merupakan pendahuluan yang berisikan:

d. Identitas peminta Visum Et Repertum e. Identitas surat permintaan Visum Et Repertum

f. Saat penerimaan surat permintaan Visum Et Repertum

g. Identitas Dokter pembuat Visum Et Repertum

h. Identitas korban/barang bukti yang dimintakan Visum Et Repertum Keterangan kejadian sebagaimana tercantum di dalam surat permintaan Visum Et Repertum

i. Bagian pemberitaan, merupakan hasil pemeriksaan dokter terhadap apa yang dilihat dan ditemukan pada barang bukti.

j. Bagian kesimpulan, merupakan kesimpulan dokter atas analisis yang dilakukan terhadap hasil pemeriksaan barang bukti.

k. Bagian penutup, merupakan pernyataan dari dokter bahwa Visum Et Repertum ini dibuat atas dasar sumpah dan janji pada waktu menerima jabatan.

1. Disebelah kanan bahwa diberikan Nama dan Tanda Tangan serta cap dinas dokter pemeriksaan. (H.M. Soedjatmiko, 2001- 4)

Dalam pembuatan Visum et repertum harus memenuhi syarat formil dan materil. Syarat formil yaitu prosedur yang harus dipenuhi yakni sebagaimana yang tercantum dalam Instruksi Kapolri No.Pol INS/E/20/IX/75 tentang tata cara permohonan/pencabutan Visum et repertum

\section{Tindak Pidana Pembunuhan}

Para pakar hukum memberikan pandangannya terkait pengetian dari strafbaar feit dengan sudut pandang mereka yang berbeda. Teguh prasetyo (2011: 217) merumuskan bahwa delik adalah perbuatan yang melanggar hukum dilakukan dengan kesalahan oleh orang yang mampu bertanggung jawab dan pelakunya diancam dengan pidana.

Maksud dan tujuan diadakannya istilah tindak pidana, perbuatan pidana, maupun peristiwa hukum dan sebagainya itu adalah untuk mengalihkan bahasa dari istilah asing stafbarfeit namun belum jelas apakah disamping mengalihkan bahasa dari istilah sratfbaar feir dimaksud untuk mengalihkan makna dan pengertiannya, juga oleh karena sebagian besar kalangan ahli hukum belum jelas dan terperinci menerangkan pengertian istilah, ataukah sekedar mengalihkan bahasanya. Tindak pidana merupakan bagian dasar dari pada suatu kesalahan yang dilakukan terhadap seorang dalam melakukan suatu kejahatan. Jadi untuk adanya kesalahan hubungan antara keadaan 
dengan perbuatan yang menimbulkan celaan harus berupa kesengajaan atau kealpaan.

Dikatakan bahwa kesengajaan (opzet) dan kealpaan (culpa) adalah bentuk-bentuk kesalahan sedangkan istilah dari pengertian kesalahan (schuld) yang dapat menyebabkan terjadinya suatu tindak pidana adalah karena seseorang tersebut telah melakukan suatu perbuatan yang bersifat melawan hukum sehingga atas perbuatanya tersebut maka dia harus bertanggungjawab atas segala bentuk tindak pidana yang telah dilakukannya untuk dapat diadili dan bilamana telah terbukti benar telah terjadi suatu tindak pidana yang dilakukannya, maka dengan begitu dapat dijatuhi hukuman pidana sesuai dengan pasal yang mengaturnya. (Amir Ilyas 2012:47)

$$
\text { KUHPidana tahun } 1915 \text { pada }
$$

hakekatnya mengenal tiga macam delik, yaitu:

a. kejahatan

a. Kejahatan enteng

b. Pelanggaran

Delik-delik dapat dibagi dalam kejahatan dan pelanggaran, delik formil dan delik materil, delicta commissionis dan delicta omissionis, zelfstandige delicten dan voortgezette delicten, aflopende delicten dan voortdurende delicten, delik sengaja dan delik kealpaan, delik pilitik dan delik biasa, delik aduan dan bukan delik aduan. ( E.utrecht 1986:104-105)

Unsur - unsur tindak pidana Pada hakikatnya, setiap perbuatan pidana harus terdiri dari unsur-unsur lahiriah (fakta) oleh perbuatan, mengandung kelakuan dan akibat yang ditimbulkan karenannya. Keduanya memunculkan kejadian dalam alam lahir (dunia).

Unsur - unsur perbuatan pidana adalah:

a. Kelakuan dan akibat (sama dengan perbuatan)

b. Hal ikhwal atau keadaan yang menyertai perbuatan.

c. Keadaan tambahan yang memberatkan pidana

d. Unsur melawan hukum yang objektif

e. Unsur melawan hukum yang subjektif.

Syarat-syarat yang harus dipenuhi seseorang dapat dihukum menurut fas.1 KUUHP ialah sebagai berikut:

a. Harus ada suatu norma-hukum pidana yang tertentu,

b. Norma-hukum pidana itu harus berdasarkan suatu undang-undang, c. Norma-hukum pidana itu harus telah berlaku sebelum perbuatan itu terjadi. (Tirtaamidjaja 1955:26)

Alasan penghapus pidana yang termasuk dalam alasan pembenar yang terdapat dalam KUHP adalah:

a. Keadaan Darurat (Nootoestand)

b. Pembelaan terpaksa

c. Melaksanakan ketentuan Undang-undang.

d. Melaksanakan perintah jabatan yang diberikan oleh penguasa yang berwenang.

Terdapat beberapa Jenis tindak pidana diantaranya yaitu :

a. Delik formal (formil) dan materil (materil)

b. Delik Dolus dan delik Culpa

c. Delik Commissionis, delik Omissionis, delik

d. Delik Aduan dan delik Biasa (bukan aduan)

e. Delik ekonomi

f. Delik sederhana dan delik yang ada pemberatannya/peringannya.

g. Delik yang berlangsung terus menerus

Terdapat jenis-jenis delik yang lain menurut dari mana kita meninjau delik tersebut, antara lain:

1) Delik berturut-turut (Voortgezet delict)

2) Delik yang berlangsung terus

3) Delik berkualifikasi (gequalificeerd)

4) Delik dengan privilege

5) Delik politik

6) Delik propria. (Teguh prasetyo, 2011: 62)

Adami Chazawi (2010:57), mengatakan bahwa apabila rumusan tersebut dirinci unsurunsurnya, maka terdiri dari :

a. Perbuatan : menghilangkan nyawa;

b. Obyeknya : nyawa orang lain;

c. Adanya hubungan sebab dan akibat antara perbuatan dan akibat kematian.

Dasar hukum dalam tindak pidana pembunuhan dalam Kitab Undang-undang Hukum Pidana (KUHP) diatur dalam bab XIX tentang kejahatan terhadap nyawa yakni pasal 338 sampai 350. Adapun unsur-unsur dari pasal 338 KUHP:

a. Setiap orang;

b. Dengan sengaja;

c. Merampas nyawa orang lain. ( kita Undangundang Hukum Pidana dan Penjelasannya)

Seperti yang di ketahui dalam KUHP, kejahatan terhadap nyawa orang lain diatur dalam buku II Bab XIX, yakni dari pasal 338 sampai pada pasal 340 KUHPidana. Dengan memperhatikan ketentuan-ketentuan pada pasal tersebut, menurut sistematis KUHP. Secara umum jenis kejahatan terhadap nyawa dapat dikelompokkan menjadi tiga jenis dalam KUHP. 


\section{E. Pembuktian Dalam Perkara Pidana}

Pembuktian adalah ketentuan yang berisi pengarisan atau pedoman tentang tata cara yang dibenarkan undang-undang untuk membuktikan kesalahan yang didakwakan kepada terdakwa, dimana pembuktian merupakan ketentuan yang mengatur alat-alat bukti yang dibenarkan undang-undang dan yang boleh dipergunakan hakim adalah membuktikan kesalahan yang didakwakan. Pembuktian dalam perkara pidana berbeda dengan pembuktian dala perkara perdata. Pembuktian merupakan salah satu unsur yang penting dalam hukum acara pidana, dimana mencamtumkan bersalah atau tidaknya seorang terdakwa dalam persidangan. ( lili mulyadi 2007 : 152).

Ketentuan pembuktian dalam hukum acara pidana terletak didalam Pasal 183 Undang-undang Nomor 8 Tahun 1981 tentang Hukum Acara Pidana, Di dalam Pasal 4 Peraturan Kepala Kepolisian Negara Republik Indonesia Nomor 14 Tahun 2012 tentang Manajemen Penyidikan Tindak Pidana ("Perkap 14/2012), dasar dilakukan penyidikan adalah:

a. laporan polisi/pengaduan;

b. surat perintah tugas;

c. laporan hasil penyelidikan (LHP);

d. surat perintah penyidikan; dan

e. Surat Pemberitahuan Dimulainya Penyidikan (SPDP).

Penjelasan mengenai alat bukti yang sah adalah sebagai berikut:

a. Keterangan Saksi

b. Keterangan ahli.

c. Surat

d. Petunjuk

e. Keteragan terdakwa

\section{METODE PENELITIAN}

Jenis Penelitian yang digunakan dalam penelitian ini adalah penelitian deskriptif kualitatif, yaitu menggambarkan hasil penelitian dengan mendeskripsikan fenomena-fenomena dan data aktual yang diperoleh dalam proses penelitian. Penelitian ini bersifat deskriptif kualitatif yang bermaksud untuk mendeskripsikan Kedudukan Visum Et Repertum dalam pengungkapan delik pembunuhan diwilayah Hukum Polrestabes Makassar.

Untuk memperoleh data dan informasi yang dibutuhkan dalam rangka pelaksanaan penelitian ini, maka penelitian ini dilakukan di kota Makassar, wilayah Hukum Polrestabes
Makassar jalan Ahmad Yani. Adapun pertimbangan dipilihnya lokasi penelitian ini berdasarkan bahwa pihak kepolisian yang berwenang menangani tindak pidana pembunuhan.

Fokus penelitian ini adalah Persepsi masyarakat terhadap Visum Et Repertum, kekuatan Visum Et Repertum dan penghambat pembuatan Visum Et Repertum sebagai alat bukti dalam pengungkapan delik pembunuhan. pengamatan dikonsep tualisasikan fokus penelitian, maka fokus tersebut perlu di deskripsikan secara kongkrit, spesifik dan operasional sebagai berikut: 1.Persepsi masyarakat yang dimaksud dalam penelitian ini adalah alasan masyarakat menolak untuk dilakukannya pemeriksaan terhadap tubuh mayat. 2.Visum Et Repertum yang dimaksud dalam penelitian ini adalah kesimpulan yang dibuat oleh dokter forensik setelah melakukan tindakan pemeriksaan terhadap bagian tubuh mayat dan diberikan kepada penyidik. 3. Kekuatan yang dimaksud dalam penelitian ini adalah mutlak atau tidaknya Visum Et Repertum dalam pengungkapan delik pembunuhan. 4. Penghambat yang dimaksud dalam penelitian ini adalah hal-hal penghambat yang dihadapai pihak yang berwenang dalam membuat Visum et Repertum

Peneltian ini menggunakan Teknik pengumpulan data yang digunakan penelitian dalam penelitian ini adalah :

1. Observasi

Observasi yang dilakukan untuk melihat fakta yang terjadi dilapangan yaitu dengan pengamatan langsung pada kondisi yang terjadi di lokasi penelitian terebut, yang dalam hal ini pengamatan terhadap kedudukan Visum Et Repertum dalam pengungkapan delik pembunuhan. Observasi awal yang dilakukan oleh penulis pada bulan desember 2017. Yang dilakukan pada masyarakat yang menolak memberikan izin dilakukan pemeriksaan pada tubuh mayat yang ada diwilayah hukum polrestabes Makassar dan kantor polrestabes Makassar.

2. Wawancara

Wawancara yang telah dilakukan diharapkan mendapatkan informasi yang sebenarnya mengenai kedudukan Visum Et Repertum dalam pengungkapan delik pembunuhan di wilayah hukum polrestabes Makassar. Wawancara dengan informan atau orang yang memberi informasi tentang situasi dan kondisi latar belakang penelirian, antara 
lain: a. Masyarakat yang menolak memberikan izin kepada kepolisian untuk membuat surat permintaan pemeriksaan kepada dokter forensik untuk dilakukan pemeriksaan pada tubuh mayat baik pada bagian luar maupun pada bagian dalam tubuh mayat. Data yang diperoleh dari informan yang mewakili masyarakat yang menolak memberikan izin dilakukan pemeriksaan pada mayat adalah $\mathrm{Hj}$. Hasia, Dg.Matta, dan Ibu Neni. b. Penyidik yang menangani kasus pembunuhan di wilayah hukum polrestabes Makassar adalah Bripda Andi mandacingi, Brigpol Suliswanto, Bapak Akbar dan Bripka Andi Darmawan.

3. Dokumentasi

Teknik dokumentasi yang telah dilakukan oleh peneliti yaitu berupa dokumentasi dalam bentuk dokumen/data, foto, rekaman pada saat melakukan penelitian dengan masyarakat dan penyidik.

\section{HASIL DAN PEMBAHASAN}

\section{Persepsi Masyarakat terhadap Visum Et Repertum dalam pengungkapan delik pembunuhan.}

Visum Et Repertum berisikan hasil pemeriksaan yang dilakukan oleh dokter forensik sesuai dengan apa yang dilihatnya, dalam tindakan pemeriksan tersebut dapat diketahui penyebab kematian mayat, waktu kematian mayat. karena pada kasus tindak pidana pembunuhan atau kasus kematian yang tidak wajar yang tidak memiliki bukti yang kuat sehingga membutuhkan pemeriksaan pada tubuh mayat namun tidak mungkin tubuh mayat dibawah kepersidangan sehingga diperlukan pemeriksaan yang dilakukan oleh dokter forensik. jadi, sudah sangat jelas bahwa pemeriksaan pada mayat sangat penting dilakukan.

Dari hasil penelitian melalui wawancara akan dibahas mengenai Persepsi masyarakat terhadap Visum et Repertum dalam pengungkapan delik pembunuhan. Berdasarkan hasil wawancara yang telah dilakukan terhadap masyarakat yang menolak memberikan izin dilakukan pemeriksaan pada tubuh mayat yang berada diwilayah hukum polrestabes Makassar yaitu ibu Hj.Hasia, ibu Neni, dan bapak Daeng Matta. mengenai Persepsi masyarakat yang tidak memberikan izin untuk dilakukan pemeriksaan terhadap mayat karena tindakan tersebut dapat menundah waktu pemakaman, pihak kelurga telah mengiklaskan kematian mayat, pihak keluarga merasa kasihan dengan tubuh mayat apabila dilakukan pembelahan oleh dokter forensik dan pihak keluarga menganggap tindakan autopsi tidak manusiawi.

Pernnyataan dari masyarakat diperkuat oleh keterangan penyidik yang menyatakan bahwa adanya penolakan dari keluarga mayat untuk dilakukan tindakan autopsy dengan berbagai alasan, diantaranya adanya opini masyarakat mengenai pengambilan organ tubuh pada mayat, keluarga mayat telah mengiklaskan kematian mayat.

Berdasarkan dari hasil wawancara terhadap masyrakat yang menolak memberikan izin dilakukan tindakan autopsy dan pihak kepolisian pada bagia jatanras polrestabes Makassar dapat dilihat bahwa masyarakat menolak disebabkan adanya opini masyarakat atau keluarga koban mengenai adanya ekspolitasi organ tubuh pada mayat, tumbuhnya pemahaman dimasyarakat bahwa mayat harus dimakamkan secepatnya, tindakan pembelahan tubuh mayat tidak manusiawi dan adanya rasa kasihan terhadap mayat.

Dapat disimpulkan bahwa pembuktian dengan menggunakan alat bukti Visum Et Repertum dapat dilakukan setelah adanya persetujuan dari pihak keluarga korban. Artinya, keluarga yang dapat mengatur jalannya proses penyelidikan. Hal ini sesuai dengan Teori yang dikemukakan oleh Lawrence M. friedman yaitu teori tentang Budaya Hukum, budaya hukum adalah sikap manusia terhadap hukum dan sistem hukum, kepercayaan, nilai, pemikiran serta harapannya. Dengan kata lain, bagian dari budaya umum itulah yang menyangkut sistem hukum. Pemikiran dan pendapat ini sedikit banyak menjadi penentu jalannya proses hukum. Sehingga budaya hukum adalah suasana pikiran sosial dan kekuatan sosial yang menentukan bagaiamana hukum digunakan, dihindari dan disalahgunakan.

\section{Kekuatan Visum Et Repertum dalam pengungkapan delik pembunuhan}

Dari hasil penelitian melalui teknik wawancara akan dibahas mengenai kekuatan Visum Et Repertum dalam pengungkapan delik pembunuhan. Adapun pembahasannya, yaitu Kedudukan alat bukti Visum Et Repertum adalah sebagai alat bukti surat dan juga dapat menjadi keterangan ahli. Kekuatan alat bukti Visum Et Repertum sama dengan alat bukti yang lain. Dengan melampirkan Visum et Repertum dalam suatu berkas perkara oleh penyidik atau pada tahap pemeriksaan dalam proses penuntutan 
oleh penuntut umum, setelah dinyatakan cukup hasil pemeriksaan dari perkara pidana yang didakwakan kepada terdakwa, kemudian dianjurkan ke persidangan, maka alat bukti surat Visum Et Repertum termasuk alat bukti sah. Dalam hukum acara pidana sebagaimana yang ditentukan dalam Undang-undang tentang KUHAP sama sekali tidak mengatur ketentuan yang khusus tentang nilai kekuatan pembuktian surat.

Meskipun Visum Et Repertum tidak mutlak harus ada, namun dalam tindak pidana yang objeknya adalah tubuh manusia, misalnya pembunuhan maka sebaiknya dilengkapi dengan Visu Et Repertum karena tidak mungkin mayat yang dibawah ke pengadilan sebagai barang bukti. Jika beberapa orang saksi melihat terjadinya pembunuhan atau penganiayaan dan didukung dengan keterangan terdakwa serta hakim yakin atas kesalahan terdakwa, maka terdakwa sudah dapat dipidana meskipun tidak disertai dengan Visum Et Repertum. Namun apabila tidak ada saksi yang melihat terjadinya pembunuhan sangat diharapkan adanya Visum Et Repertum karna dapat menyakinkan hakim bahwa benar-benar penyebab kematian korban karena adanya tindakan pembunuhan.

Dari hasil penelitian melalui teknik wawancara yang dilakukan dengan penyidik pada bagian jatanras polrestabes Makassar dapat disimpulkan bahwa Visum Et Repertum sebagai alat bukti dalam delik pembunuhan memiliki kekuatan yang mutlak namun tidak mutlak untuk dilakukan disetiap kasus atau delik pembunuhan. Kekuatan pembuktian Visum Et Repertum sebagai alat bukti dalam delik pembunuhan merupakan alat bukti yang sempurna tentang apa saja yang tercantum didalamnya, jadi kesimpulan wajib dipercaya sepanjang belum ada bukti lain yang melemahkan. Tidak ada satu alat bukti pun yang dapat dikatakan sebagai alat bukti terkuat, Visum Et Repertum dapat memiliki kekuatan yang mutlak karena dapat membuktikan bahwa tersangka benar telah melakukan suatu perbuatan tindak pidana pembunuhan atau tidak. Visum Et Repertum tidak bisa berdiri sendiri karena setiap putusan pemidanaan harus tetap didasarkan dengan minimal dua alat bukti yang sah ditambah dengan keyakinan hakim. Hal ini sesuai dengan ketentuan pembuktian dalam hukum acara pidana terletak dalam pasal 183 Undang-undang Nomor 8 Tahun 1981 tentang hukum acara pidana.
Hal ini sesuai dengan Teory yang dikemukakan oleh Rusli Muhammad yaitu Teory pembuktian menurut undang-undang secara negativ, yaitu dalam sistem pembuktian ini untuk menyatakan salah tidaknya terdakwa tidak hanya cukup berdasarkan keyakinan hakim, tetapi harus didukung oleh alat-alat bukti yang ditentukan oleh undang-undang, sehingga dengan demikian, seorang terdakwa harus dapat dinyatakan bersalah apabila kesalahan kepadanya dapat dibuktikan dengan cara dan alat-alat bukti yang sah menurut undang-undang dan sekaligus keterbuktian kesalahan tersebut diikuti oleh keyakinan hakim, sehingga sistem pembuktian ini adalah memadukan unsur obyektif dan subyektif dalam menentukan salah tidaknya terdakwa.

\section{Penghambat Visum Et Repertum dalam pengungkapan delik pembunuhan}

Dari hasil penelitian melalui teknik wawancara akan dibahas mengenai penghambat pembuatan Visum Et Repertum dalam pengungkapan delik pembunuhan, adapun pembahasannya yaitu, Visum Et Repertum sebagai alat bukti dalam pembuktian delik pembunuhan sangat penting untuk disertakan. Kekuatan alat bukti Visum Et Repertum sangat mutlak karena hasil dari pemeriksaan tubuh mayat. Namun masi adanya delik pembunuhan yang dalam proses pembuktiannya tidak disertai dengan alat bukti Visum Et Repertum.

Berdasarkan dari hasil wawancara dengan penyidik pembantu pada bagian Jatanras Polrestabes Makassar dapat disimpulkan bahwa masyarakat tidak memberikan izin karena adanya opini masyarakat tentang eksplolitasi organ tubuh yang dilakukan dokter forensik pada saat pemeriksaan tubuh mayat. sehingga muncul berbagai alasan dari keluarga mayat untuk tidak memberikan izin dilakukannya autopsi

Hal ini dikarenakan tindakan pemeriksaan tubuh jenazah pada bagian dalam dilakukan dengan cara membelah bagian kepala dan dada hingga perut jenazah berbentuk $\mathrm{Y}$ kemudian mengeluarkan dan mengambil sampel setiap organ-organ yang terdapat didalam tubuh mayat dan hal tersebut meninggalkan bekas jahitan. Sehingga hal tersebut yang membuat masyarakat beranggapan bahwa organ-organ yang ada ditubuh jenazah telah diambil.

Hal ini sesuai dengan Teori yang dikemukakan oleh Lawrence M. friedman yaitu teori tentang Budaya Hukum, budaya hukum adalah sikap manusia terhadap hukum dan 
sistem hukum, kepercayaan, nilai, pemikiran serta harapannya. Dengan kata lain, bagian dari budaya umum itulah yang menyangkut sistem hukum. Pemikiran dan pendapat ini sedikit banyak menjadi penentu jalannya proses hukum. Sehingga budaya hukum adalah suasana pikiran sosial dan kekuatan sosial yang menentukan bagaiamana hukum digunakan, dihindari dan disalahgunakan.

Untuk mengatasi kendala dari Opini masyarakat tentang pengambilan organ-organ tubuh jenazah yang dilakukan dokter forensik. Solusi yang dapat dilakukan dengan melakukan penyuluhan kepada masyarakat yang berada diwilayah hukum polrestabes Makassar bahwa tidak ada pengambilan organ tubuh mayat dilakukan oleh dokter forensik dikarenakan organ tubuh manusia tidak berfungsi lagi setelah manusia meninggal. Dan agar Masyarakat mengetahui tujuan dilakukannya pemeriksaan pada tubuh mayat bagian dalam. Yang pada intinya dapat memberikan jawaban penyebab kematian mayat dan sebagai pertimbangan hakim dalam pengambilan keputusan.

\section{SIMPULAN DAN SARAN}

Berdasarkan hasil penelitian dan pembahasan dapat ditarik kesimpulan sebagai berikut:

1. Pembuatan Visum Et Repertum sebagai alat bukti dalam pengungkapan delik pembunuhan yaitu masih ada menghadapai penolakan dari masyarakat dengan alasan telah mengiklaskan, merasa kasihan dengan mayat, menganggap tindakan tersebut tidak manusiawi, dan faktor agama.

2. Kekuatan Visum Et Repertum memiliki kekuatan yang mutlak, namun Visum Et Repertum tidak mutlak dilakukan disetiap kasus pembunuhan. Kekuatan pembuktian Visum Et Repertum merupakan alat bukti yang sempurna tentang apa saja yang tercantum didalamnya. Visum Et Repertum tidak bisa berdiri sendiri karena setiap putusan pemidanaan harus tetap didasarkan dengan minimal dua alat bukti yang sah ditambah dengan keyakinan hakim.

3. Penghambat pembuatan Visum Et Repertum sebagai alat bukti dalam pengungkapan delik pembunuhan yaitu adanya opini masyarakat tentang pengambilan organ-organ tubuh mayat yang dilakukan dokter forensik.

Saran dari penelitian ini adalah: (1) Bagi masyarakat hendaknya dapat memberikan pesetujuan atau memberikan izin kepada pihak penyidik untuk mengajukan permintaan pemeriksaan kepada dokter forensik. Pemeriksaan yang dilakukan dokter forensik yaitu pada tubuh mayat baik pada bagian luar maupun pada bagian dalam. Yang bertujuan untuk mengetahui penyebab kematian dan waktu kematian mayat; (2) Diharapkan bagi pihak yang berwenang dapat memberikan pemahaman kepada masyarakat mengenai kedudukan bukti Visum Et Repertum dalam delik pidana pembunuhan. Sehingga diharapkan pihak keluarga mengetahui bahwa tindakan autopsi atau pemeriksaan tubuh bagian dalam dan luar mayat sangat penting dilakukan; (3) Diharapkan bagi pihak yang berwenang memberikan sosialisasi kepada masyarakat bahwa tidak ada tindakan pengambilan organ manusia pada tubuh mayat yang dilakukan oleh dokter forensik karena dokter forensic telah diambil sumpahnya dan organ pada tubuh manusia yang telah dinyatakan meninggal sudah tidak berfungsi.

\section{DAFTAR RUJUKAN}

\section{Buku}

Adami Chazawi. 2010. Kejahatan Terhadap Nyawa dan Tubuh. Jakarta: Grafindo

Akyas Azhari. 2004. Psikologi Perkembangan. Jakarta : Teraju Mizan Publika

Amir Ilyas. 2012. Asas-asas Hukum Pidana. Yogyakarta : Mahakarya Rangkang Barda Nawawi Arief. 2010. Perbandingan Hukum Pidana Edisi Revisi. Jakarta : PT RajaGrafindo Persada

E.Utrecht.1986. Hukum Pidana I. Pustaka Tinta Mas: Bandung

Lawrence M. Friedman. 2001. American Law An Introduction Second Edition Hukum Amerika Sebuah Pengantar. Jakarta : PT.TataNusa

Lili Mulyadi. 2007. Hukum Acara Pidana. Bandung: PT Citra Aditya Bakti.

R. Atang Ranoemihardja. 1983. Ilmu Kedokteran Kehakiman Forensic Science Ed. 2, Bandung : Tarsito,

R. Soeparmono. 2002. Peranan Visum et Repertum, Bandung: Sinar Grafika,

Teguh prasetyo. 2011. Hukum Pidana Edisi Revisi. Jakarta: Rajawali Pers

Tirtaamidjaja. 1955. Pokok-pokok Hukum Pidana. Djakarta : Fasco.

\section{A. Undang - undang}


Phinisi Integration Review. Vol 2(2) Agustus 2019

Undang - Undang Dasar Negara Republik Indonesia Tahun 1945

Undang-undang kepolisian Nomor 2 tahun 2002 tentang tugas dan fungsi kepolisian negara republic indonesia

Kitab Undang-undang Hukum Pidana dan Undang-undang Hukum Acara Pidana

Undang-undang Nomor 8 Tahun 1981 tentang Kitab Undang-undang Hukum Acara Pidana

\section{B. Sumber Lain}

http://manado.tribunnews.com/amp/2018/04/22/ wajib-tahu-inilah-yang-terjadi-saatautopsi-mayat-yang-dilakukan-olehdokter-ahli. Diakses pada 14 november 2018

https://www.bps.go.id/publication/2017/12/22/1 97562b7ad0ced87c08fada5/statistikkriminal-2017.html, diakses 20 oktober 2018

https://lifestyle.kompas.com/read/2012/05/16/07 43544/Anggapan.Keliru.Tentang.Otopsi .di.Masyarakat 